\title{
Editorial
}

\section{Housing Real Estate Economics and Finance}

\author{
Rita Yi Man Li
}

check for

Citation: Li, Rita Yi Man. 2022.

Housing Real Estate Economics and Finance. Journal of Risk and Financial Management 15: 121. https:// doi.org/10.3390/jrfm15030121

Received: 28 February 2022

Accepted: 1 March 2022

Published: 4 March 2022

Publisher's Note: MDPI stays neutral with regard to jurisdictional claims in published maps and institutional affiliations.

Copyright: (C) 2022 by the author Licensee MDPI, Basel, Switzerland. This article is an open access article distributed under the terms and conditions of the Creative Commons Attribution (CC BY) license (https:// creativecommons.org/licenses/by/ $4.0 /)$.
Department of Economics and Finance/Sustainable Real Estate Research Center, Hong Kong Shue Yan University, Hong Kong; ymli@hksyu.edu

\begin{abstract}
Housing research is one of the hot topics in many countries. This paper provides a quick review of the housing economics research in the US, Sweden, Latvia, China, Corsica, and Italy published in this special issue. Bao and Shah studied the effects of home-sharing platforms in general and the effects of the US' Airbnb on neighbourhood rent. Wilhelmsson's results showed that interest rates directly affected house prices and indirectly affected bank loans in Sweden. Caudill and Mixon threw light on the relative negotiating power of the buyer and seller as a key element of real estate price models. Čirjevskis presented a real application of "step-by-step" valuation options for real estate development projects as a managerial risk management tool for similar real estate development projects in the EU to make investment decisions during COVID-19 and in the post-COVID-19 era. Pelizza and Schenk-Hoppé used an exponential Ornstein-Uhlenbeck process to model price dynamics provincially and regionally to estimate the liquidation value.
\end{abstract}

Keywords: housing economics; housing finance; home-sharing; investment; real estate price; mortgage; bank loans

Homeownership is the dream in many nations. It is affected by many different factors, such as generations (Li 2015). Studying the factors that affect housing prices has been a significant focus for many years. Previous research has shed light on housing estates (Li et al. 2021), landfill externalities ( $\mathrm{Li}$ and Li 2018), and exchange rates (Li and Chau 2016).

These estate economics and finance issues were mainly determined based on housing economics and finance research in the US, Sweden, Latvia, China, Corsica, and Italy. This research covered short-term accommodations, such as Airbnbs in the US, the interplay between housing and the financial market in Sweden, the negotiating power of the buyer and seller in the Corsican apartment market, urban leverage on housing price in China, and real-option valuation application for real estate development projects.

Bao and Shah (2020) explored the effects of home-sharing platforms in general and the effects of Airbnb on neighbourhood rent. Using consumer-facing Airbnb data from the US gathered between 2013-2017 and rental data from the American online real estate database Zillow, the study explores Airbnb penetration and rental rates. The findings indicated that Airbnb's impact on rent depends on the individual features of a neighbourhood. The study urged that policymakers should implement tailored solutions to reduce the platform's negative impacts while taking advantage of its economic benefits.

Wilhelmsson (2020)'s research attempted to answer the question of what role the housing market plays in the transmission mechanism and does the impact remain consistent over time? The research question considered the importance of the housing market for the transportation system by using an eight-variable structural vector autoregression model of the Swedish economy from 1993 to 2018, covering the internet bubble and the financial crises in 2000 and 2008 respectively. The results showed that interest rates directly affected house prices and indirectly affected bank loans. In addition, the role of banking credit has grown over time. There had been substantial growth in household debt in Sweden and elsewhere. Based on the results, it is possible to assess and anticipate the potential effects of housing prices when interest rates change. 
Caudill and Mixon (2020) shed light on the relative negotiating power of the buyer and seller as a key element of real estate price models. Conventional research on real estate had sought to examine trading effects in hedonic regression models. Previous research proposed a procedure for estimating negotiation effects in hedonic regression models that critically depended on substitution to remove bias from the omitted variables. This study showed that the proposed solution that was often cited in the real estate economics literature does not solve the problem of omitted variables. Both models produced bias estimates of bargaining power when specific property characteristics were omitted. A classic hedonic regression model of real estate prices using Corsican apartment data supports their assertion, even when the symmetry of the trading power hypothesis is relaxed.

Urban leverage hurt housing prices by influencing credit availability. Using panel data and hedonic models from 236 cities, Lu and Shen (2022) found that urban leverage negatively impacted housing prices in first- and second-tier cities, while no impacts were observed on third fourth-tier cities. Furthermore, the difference analysis indicated that purchasing restraint policies amplify the negative effect of urban leverage on housing prices. In short, urban leverage is an important determinant of housing prices in China.

Čirjevskis (2021) found that the EU real estate market had undergone a severe global financial crisis in 2008-2009 and that it later successfully recovered. Nevertheless, these markets experienced significant uncertainty due to COVID-19 and increased housing market volatility. This research shed light on the Latvian real estate market, which experienced similar economic uncertainty. It presented a real application of "step-by-step" valuation options for real estate development projects as a managerial risk management tool for similar real estate development projects in the EU to make investment decisions during COVID-19 and in the post-COVID-19 era.

Pelizza and Schenk-Hoppé (2020) provided the expected recovery rates for Italian defaulted mortgages backed by residential or commercial real estate. They used an exponential Ornstein-Uhlenbeck process to model price dynamics provincially and regionally to estimate the liquidation value. Their findings showed that rating agencies such as Moody's, which used geometric Brownian movement to model the price dynamics, had higher recovery rates. Hence, the non-performing mortgages held by Italian banks might be overvalued.

Mohammad Ebrahimzadeh Sepasgozar et al. (2020) noted that one of the most critical challenges for e-government and e-banking is accurately estimating the factors that significantly affect impact customer behaviour. Without knowing these factors, it would be impossible to predict new the acceptance of new services and acquire a competitive advantage. This research aimed to identify user intentions using the Technology Acceptance Model, technology adoption theory, technology diffusion theory, and planned behaviour theory in the Mehr Bank in Iran. The data were collected through questionnaires from two hundred clients and employees who worked at or had business dealings with Mehr Bank. The results confirmed the direct impact of "perceived utility" and "perceived ease of use" on user attitudes.

Funding: This research received no external funding.

Conflicts of Interest: The author declares no conflict of interest.

\section{References}

Bao, Helen X. H., and Saul Shah. 2020. The Impact of Home Sharing on Residential Real Estate Markets. Journal of Risk and Financial Management 13: 161. [CrossRef]

Caudill, Steven B., and Franklin G. Mixon. 2020. Estimating Bargaining Power in Real Estate Pricing Models: Conceptual and Empirical Issues. Journal of Risk and Financial Management 13: 105. [CrossRef]

Čirjevskis, Andrejs. 2021. Value Maximizing Decisions in the Real Estate Market: Real Options Valuation Approach. Journal of Risk and Financial Management 14: 278. [CrossRef]

Li, Na, Rita Yi Man Li, and Ruihui Pu. 2021. What is in a name? A modern interpretation from housing price in Hong Kong. Pacific Rim Property Research Journal 27: 55-74. [CrossRef] 
Li, Rita Yi Man. 2015. Generation X and Y's demand for homeownership in Hong Kong. Pacific Rim Property Research Journal 21 : 15-36. [CrossRef]

Li, Rita Yi Man, and Kwong Wing Chau. 2016. Econometric Analyses of International Housing Markets. London: Routledge.

Li, Rita Yi Man, and Herru Ching Yu Li. 2018. Have Housing Prices Gone with the Smelly Wind? Big Data Analysis on Landfill in Hong Kong. Sustainability 10: 341. [CrossRef]

Lu, Wanying, and Jianfu Shen. 2022. Urban Leverage and Housing Price in China. Journal of Risk and Financial Management 15: 87. [CrossRef]

Mohammad Ebrahimzadeh Sepasgozar, Fatemeh, Usef Ramzani, Sabbar Ebrahimzadeh, Sharifeh Sargolzae, and Samad Sepasgozar. 2020. Technology Acceptance in e-Governance: A Case of a Finance Organization. Journal of Risk and Financial Management 13: 138. [CrossRef]

Pelizza, Michela, and Klaus R. Schenk-Hoppé. 2020. Pricing Defaulted Italian Mortgages. Journal of Risk and Financial Management 13: 31. [CrossRef]

Wilhelmsson, Mats. 2020. What Role Does the Housing Market Play for the Macroeconomic Transmission Mechanism? Journal of Risk and Financial Management 13: 112. [CrossRef] 